\title{
Energy efficiency and its relationship with milk, body, and intake traits and energy status among primiparous Nordic Red dairy cattle
}

\author{
P. Mäntysaari, ${ }^{* 1}$ A.-E. Liinamo, $†$ and E. A. Mäntysaari† \\ *Animal Production Research, and \\ †Biotechnology and Food Research, MTT Agrifood Research Finland, FI-31600 Jokioinen, Finland
}

\begin{abstract}
Existing variation in energy efficiency and its relationship with milk yield and milk composition, body weight and body condition, feed intake, and energy status was studied in primiparous Nordic Red dairy cattle with data including 3,752 weekly records from 145 cows. Energy efficiency was defined as energy conversion efficiency (ECE) and as residual energy intake (REI) estimated based on Finnish feeding standards $\left(\mathrm{REI}_{1}\right)$ or from the current data $\left(\mathrm{REI}_{2}\right)$. The results indicated true phenotypic variation in energy efficiency of the cows. The proportion of total variance due to the animal was 0.35 for $\mathrm{REI}_{1}, 0.30$ for $\mathrm{REI}_{2}$, and 0.50 for ECE. The high efficiency based on ECE was associated with increased mobilization of body reserves $(\mathrm{r}=$ $-0.50)$ and decreased dry matter intake $(\mathrm{r}=-0.51)$. With REI as an energy efficiency measure, the increased efficiency was associated with a large decrease in feed intake $\left(\mathrm{REI}_{1}: \mathrm{r}=0.60\right.$; REI2: $\left.\mathrm{r}=0.74\right)$ without any effect on body weight change $\left(\mathrm{REI}_{1}: \mathrm{r}=0.13\right.$; REI2: $\mathrm{r}$ $=0.00)$. Increased efficiency based on ECE and REI was associated with increased milk yield (ECE: $\mathrm{r}=$ $\left.0.58 ; \mathrm{REI}_{1}: \mathrm{r}=-0.41\right)$. A clear effect of stage of lactation on REI was found, which could be caused by true differences in utilization of metabolizable energy during lactation. However, it might also be related, in part, to the lack of knowledge of the composition of body weight change in the beginning of lactation.
\end{abstract}

Key words: energy efficiency, milk production

\section{INTRODUCTION}

Feed cost is a major expense in dairy production; therefore, cow feed intake and the ability to convert feed energy to milk energy is an important concern within the dairy industry. In addition, from an environmental point of view, improving energy efficiency in milk production is desired because it decreases nutrient

Received July 5, 2011.

Accepted February 5, 2012.

${ }^{1}$ Corresponding author: paivi.mantysaari@mtt.fi and greenhouse gas emissions per animal. In addition, understanding the efficiency of energy utilization on different diets would be useful for feeding decisions and in ration formulation.

Breeding programs for dairy cows in most countries have traditionally focused on production traits (Miglior et al., 2005). The increase in milk production has led to an increase in feed intake but also in enhancement of energy conversion efficiency (ECE) because of lower genetic correlation between milk yield and feed intake than between milk yield and ECE (Korver, 1988). Energy conversion efficiency is calculated by dividing ECM, or milk energy output, by energy intake. However, ECE can be problematic in that higher efficiency with increased milk production is often associated with increased mobilization of body reserves, especially in the beginning of lactation. The lost body reserves need to be gained back in later lactation, which leads to decreases in efficiency at that stage. In addition, increased loss of body reserves can impair reproduction performance (de Vries et al., 1999; Roche et al., 2007) and increase risk for health problems (Collard et al., 2000).

An alternative measure for energy efficiency is residual energy intake (REI), which is defined as actual energy intake minus the predicted energy requirement, the latter being estimated from lactation performance, BW, BW change, and energy needed for pregnancy. Thus, REI reflects the remaining energy available after its use for milk, maintenance, and growth has been accounted for. The lower the REI value, the more efficiently energy has been utilized. In the calculation of REI, the changes in BW are modeled, and therefore REI should be less related to BW mobilization in early lactation than ECE.

Differences in energy efficiency have been reported among dairy breeds, but also between genotypes within breed (Legates, 1990; Coleman et al., 2010). In contrast, some studies observed no significant variation in REI (Prendiville et al., 2009) or ECE (Smothers et al., 1986) between breeds or genotypes. No studies have been published to date concerning energetic efficiency and its relationship with other traits in Nordic Red 
dairy cattle (RDC). The purpose of this study was to evaluate the existing variation in energy efficiency among the Nordic RDC cows across their first lactation, and to address the associations between the efficiency measures and production, feed intake, and body traits. In this paper, the phenotypic aspects of efficiency variation and associations are described. A separate paper will address the genetic background of the variation.

\section{MATERIALS AND METHODS}

\section{Animals and Feeding}

The data used in this study were collected in the MTT Agrifood Research Rehtijärvi MOET (multipleovulation embryo transfer) herd during the period from September 2006 to January 2009. Daily production and feed intake of 145 primiparous Nordic RDC cows were followed from calving to d 210 of lactation. The collected data included 3,752 weekly records. The animals were donor candidates in the Nordic embryo transfer breeding program ASMO, and thereafter most were dams of future AI bulls.

All cows were fed ad libitum a TMR containing home blend concentrate mix (mix A) and grass silage. Mix A included $(\mathrm{g} / \mathrm{kg})$ barley (301), oat (300), sugar beet pulp (109), rapeseed meal (259), and mineral and vitamin mix (31). Grass silage was prepared from a first-cut timothy (Phleum pratense) and meadow fescue (Festuca pratensis) sward using a formic acid-based additive. The amount of concentrate in TMR was $37 \%$ in DM. In addition to the TMR, cows received an additional concentrate (mixes $\mathrm{A}$ and $\mathrm{B}$ ) given on top of the TMR. Mix B included $(\mathrm{g} / \mathrm{kg})$ barley (158), oat (140), sugar beet pulp (118), rapeseed meal (554), and mineral and vitamin mix (30).

The amount of the top fed concentrate depended on the stage of lactation and digestibility of the grass silage. When the digestibility of the $\mathrm{OM}$ of silage was between 680 and $700 \mathrm{~g} / \mathrm{kg}$ of $\mathrm{DM}$, the proportion of concentrate in the diet was $52 \%$ during lactation d 1 to 150 and $45 \%$ thereafter. The amount of concentrate decreased or increased by 2 percentage units for each $10 \mathrm{~g} / \mathrm{kg}$ of DM increase or decrease in digestibility of the silage. The proportion of mix A and B in top fed concentrate was adjusted so that the $\mathrm{CP}$ concentration in concentrate was $19.5 \%$ in DM during the lactation d 1 to 150 and $18.5 \%$ thereafter.

The cows were housed in a tie-stall barn. The TMR was mixed in a mixer wagon (Järvenpään Konepaja, Forssa, Finland). Feeding of TMR and additional concentrate was carried out by a feeding robot (TR feeding robot, Pellonpaja Ltd., Ylihärmä, Finland); feeds were offered 5 times a day. To ensure ad libitum feeding, at least $5 \%$ daily refusals were required.

\section{Data Recording, Sampling, and Analyses}

Daily milk yield was recorded twice a week. Milk protein, fat, and lactose were analyzed once a week on lactation wk 1 to 8 and once a month thereafter at the laboratory of Valio Ltd. (Seinäjoki, Finland) using an infrared analyzer (MilkoScan FT6000, Foss Electric, Hillerød, Denmark). Individual feed intake was recorded daily. However, feed intakes were not recorded during the pasture period. Cows were weighed once a week after morning milking during lactation wk 1 to 8 , every other week during wk 9 to 16 , and every fourth week thereafter. Body condition scores of the cows were assessed on a scale of 1 to $5(1=$ skinny to $5=$ very fat $)$ with intervals of 0.25 (Edmonson et al., 1989) in the calving week and every other week thereafter.

A sample of grass silage was taken twice a week. These subsamples were combined to give a 3 -wk sample for analysis. Samples were stored at $-20^{\circ} \mathrm{C}$. Thawed samples were analyzed for DM, ash, CP, NDF, VFA, lactic acid, water-soluble carbohydrates, ammonia-N, and in vitro $\mathrm{OM}$ digestibility. Concentrate samples were collected once a week and combined to give a 6 -wk sample for analysis. The concentrate samples were analyzed for DM, ash, CP, ether extract, and NDF. The analyses of grass silage and concentrate samples were performed using procedures described previously by Mäntysaari et al. (2007). Chemical composition and calculated energy and protein values of the grass silage and the concentrates are given in Table 1 .

Blood samples for plasma NEFA analyses were taken from each animal from coccygeal vein at 1, 2, 3, and 5 wk postpartum. Blood was collected in heparinized tubes and stored on ice until centrifuged at $-4^{\circ} \mathrm{C}$ for 15 min at $2,000 \times g$. Plasma samples were frozen and stored at $-20^{\circ} \mathrm{C}$ for latter analyses, and NEFA were analyzed using an analytical kit (NEFA C kit, Wako Chemicals GmbH, Neuss, Germany).

\section{Study Variables and Statistical Analyses}

Metabolizable energy content for grass silage was based on in vitro (Nousiainen et al., 2003) OM digestibility (16 MJ/kg of digestible OM). The ME concentration of the concentrates was calculated from digestible nutrients (MAFF, 1975, 1984). The digestibility coefficients for the components were taken from the Finnish feed tables (MTT, 2006). Energy and nutrient content of the TMR were calculated from values of the constituents and the proportion of each component 
Table 1. Chemical composition and calculated energy and protein values of grass silage and concentrate mixes $($ mean $\pm \mathrm{SD})$

\begin{tabular}{lccc}
\hline Item & Grass silage $^{1}$ & Concentrate $^{2}$ & Concentrate B $^{3}$ \\
\hline $\mathrm{DM}, \mathrm{g} / \mathrm{kg}$ & $258.8 \pm 39.8$ & $890.7 \pm 4.9$ & $889.0 \pm 3.0$ \\
In DM, g/kg & $83.6 \pm 9.8$ & $75.5 \pm 1.9$ & $85.5 \pm 2.6$ \\
Ash & $159.9 \pm 19.9$ & $187.8 \pm 8.3$ & $249.3 \pm 6.8$ \\
CP & $\mathrm{ND}^{4}$ & $50.8 \pm 5.7$ & $70.0 \pm 2.5$ \\
Ether extract & $505.9 \pm 29.2$ & $240.9 \pm 11.4$ & \\
NDF & $702 \pm 23$ & & \\
Digestible OM & $11.2 \pm 0.4$ & $12.1 \pm 0.08$ & $12.0 \pm 0.05$ \\
Feed values in DM & $86.7 \pm 2.4$ & $119.9 \pm 1.86$ & $129.7 \pm 1.57$ \\
ME, ${ }^{5} \mathrm{MJ} / \mathrm{kg}$ & $\mathrm{AAT},{ }^{6} \mathrm{~g} / \mathrm{kg}$ & &
\end{tabular}

${ }^{1} \mathrm{pH} 4.05 \pm 0.30$, ammonia-N $42.9 \pm 10.7 \mathrm{~g} / \mathrm{kg}$ of N, soluble $\mathrm{N} 575.5 \pm 35.9 \mathrm{~g} / \mathrm{kg}$ of N, water-soluble carbohydrates $67.5 \pm 33.2 \mathrm{~g} / \mathrm{kg}$ of DM, lactic acid $53.0 \pm 18.8 \mathrm{~g} / \mathrm{kg}$ of DM, acetic acid $16.1 \pm 3.5 \mathrm{~g} / \mathrm{kg}$ of DM, propionic acid $0.33 \pm 0.47 \mathrm{~g} / \mathrm{kg}$ of DM, butyric acid $0.007 \pm 0.02 \mathrm{~g} / \mathrm{kg}$ of DM.

${ }^{2} \mathrm{~A}$ mix $(\mathrm{g} / \mathrm{kg}$ ) of barley (301), oat (300), sugar beet pulp (109), rapeseed meal (259), and mineral and vitamin $\operatorname{mix}(31)$.

${ }^{3} \mathrm{~A}$ mix $(\mathrm{g} / \mathrm{kg}$ ) of barley (158), oat (140), sugar beet pulp (118), rapeseed meal (554), and mineral and vitamin mix (30; Melica Onni, Melica Oy, Vaasa, Finland).

${ }^{4}$ Not determined.

${ }^{5} \mathrm{MAFF}(1975,1984)$.

${ }^{6}$ Amino acids absorbed from small intestine (MTT, 2006).

in the TMR, and ECM was calculated according to Sjaunja et al. (1990).

Weekly averages for feed intake and milk production for the individual cows were calculated from the daily intake and twice-per-week milk yield measurements. To calculate weekly BCS, cubic polynomial BCS curves were fitted for each animal. Then, the weekly BCS were predicted from the individual curves. Correspondingly, the weekly BW were estimated by fitting a regression function on the observed BW. A linear model with an exponential term (Wilmink 1987) was used, and the predicted values were taken from the individual animal curves.

Energy status of a cow was accessed by energy balance (EB), plasma NEFA concentration, and milk fat:protein ratio. Weekly EB was calculated for each cow using a week average feed intake, milk production, and $\mathrm{BW}$ data $[\mathrm{EB}=$ energy intake (MJ of $\mathrm{ME}$ ) - energy required for milk and maintenance (MJ of ME)]. The ME requirements (MJ) for ECM $\left(\mathrm{ME}_{\text {milk }}=5.148\right.$ $\times \mathrm{ECM})$ and for maintenance $\left(\mathrm{ME}_{\text {maintenance }}=8.307+\right.$ $0.09126 \times$ BW) were taken from the official Finnish feeding standards (MTT, 2006). Energy efficiency was estimated with $\mathrm{ECE}(\mathrm{ECE}=\mathrm{ECM} / \mathrm{ME}$ intake) and by 2 alternative REI measures. For $\mathrm{REI}_{1}$, the official Finnish energy requirements (MTT, 2006) for milk, maintenance, and BW gain or loss were subtracted from the actual total energy intake. In calculation of $\mathrm{REI}_{2}$, the requirements were estimated from the current data; that is, a multiple linear first-order regression, including week average energy output in milk, BW, and piecewise regressions of BW gain and BW loss, was used to model the weekly measures of total energy intake. Thereafter, the prediction equation residual was defined to be $\mathrm{REI}_{2}$ for the cow and each lactation week. A cow-wise mean of residuals was used as a cow $\mathrm{REI}_{2}$ measure.

To address the variance structure of energy efficiency and energy balance traits, between-cow and within-cow variances were estimated using a simple mixed model with fixed lactation week and a random cow effect (MIXED procedure; SAS Institute Inc., Cary, NC). The relationships of energy efficiency and production, intake, and body traits were described using Pearson correlations. To quantify the significance of cow differences, the average energy efficiency during wk 2 to 30 of lactation was calculated for each cow. The ECE and $\mathrm{REI}_{2}$ were used as alternative definitions in classifying the cows. Based on these averages, the cows were divided into 3 groups: the most $(25 \% ; \mathrm{n}=36)$ and the least $(25 \% ; \mathrm{n}=36)$ efficient cows, and the rest. When ECE was used as an efficiency measure, the groups were named H-ECE (high efficiency) and L-ECE (low efficiency); when $\mathrm{REI}_{2}$ was used, the groups were called H-REI (high efficiency) and L-REI (low efficiency), respectively.

\section{RESULTS}

\section{Performance and Energy Efficiency of the Cows}

Milk production and feed intake of the experimental cows are presented in Table 2 and Figure 1. The average ECM of the cows was $28.8 \mathrm{~kg} / \mathrm{d}$, varying from 16.9 to $38.1 \mathrm{~kg} / \mathrm{d}$. Cows ate an average $18.7 \mathrm{~kg}$ of DM/d, 
Table 2. Mean, standard deviation, and range of cow-wise average milk production, feed intake, BW, and BCS during lactation wk 2 to 30

\begin{tabular}{lcccc}
\hline Item & Mean & SD & Minimum & Maximum \\
\hline Milk yield, kg/d & 28.2 & 3.71 & 16.9 & 38.1 \\
ECM yield, kg/d & 28.8 & 3.58 & 18.4 & 39.5 \\
Milk composition, \% & & & & \\
Fat & 4.11 & 0.395 & 3.20 & 5.17 \\
Protein & 3.52 & 0.183 & 3.04 & 4.03 \\
Lactose & 4.70 & 0.102 & 4.42 & 5.00 \\
Intake & & & & \\
Forage, kg of DM/d & 9.6 & 0.89 & 7.3 & 11.6 \\
Concentrate, kg of DM/d & 9.1 & 0.83 & 7.1 & 10.9 \\
Total intake, kg of DM/d & 18.7 & 1.69 & 14.7 & 22.3 \\
ME MJ/d & 218.6 & 19.6 & 173.0 & 4.27 \\
CP, kg/d & 3.35 & 0.35 & 2.53 & 752 \\
BW, kg & 586 & 55.0 & 443 & 0.678 \\
BW change, kg/d & 0.195 & 0.169 & -0.306 & 3.90 \\
BCS & 3.06 & 0.28 & 2.26 & 0.030 \\
Change in BCS, unit/wk & -0.002 & 0.016 & -0.094 & \\
\hline
\end{tabular}

which corresponds to $219 \mathrm{MJ}$ of ME/d. Average BW of the cows was $586 \mathrm{~kg}$, with a range from 443 to $752 \mathrm{~kg}$ (Table 1). Cows lost BW during the first 5 wk of lactation, after which BW increased (Figure 2). The changes in BCS agree well with the changes in BW. At calving, the BCS was 3.18, on average, reaching the nadir (2.96 BCS units) in lactation wk 6 (Figure 2).

Calculated EB was lowest in the second week of lactation and turned positive in wk 6 (Figure 3). Plasma NEFA concentration during the first 5 wk of lactation was, on average, $0.247 \mathrm{mmol} / \mathrm{L}$ (Table 3 ). This value is low and did not indicate a deep negative EB. However, in individual measurements, the highest measurements of NEFA were $>0.700 \mathrm{mmol} / \mathrm{L}$. Milk fat:protein ratio, which is also considered an EB indicator, was highest during the first weeks of lactation and, in agreement with the EB, decreased thereafter.

The ECE averaged $0.133 \mathrm{~kg}$ of ECM/MJ of ME. The $\mathrm{REI}_{1}$, which was based on the Finnish feeding standards, averaged 3.2 MJ of $\mathrm{ME} / \mathrm{d}$, and mean $\mathrm{REI}_{2}$ was $0.0 \mathrm{MJ}$ of $\mathrm{ME} / \mathrm{d}$, as expected, because it was based on the energy requirements calculated from the current data (Table 3). Most of the variation in weekly energy efficiency was within cows but between-cow variation

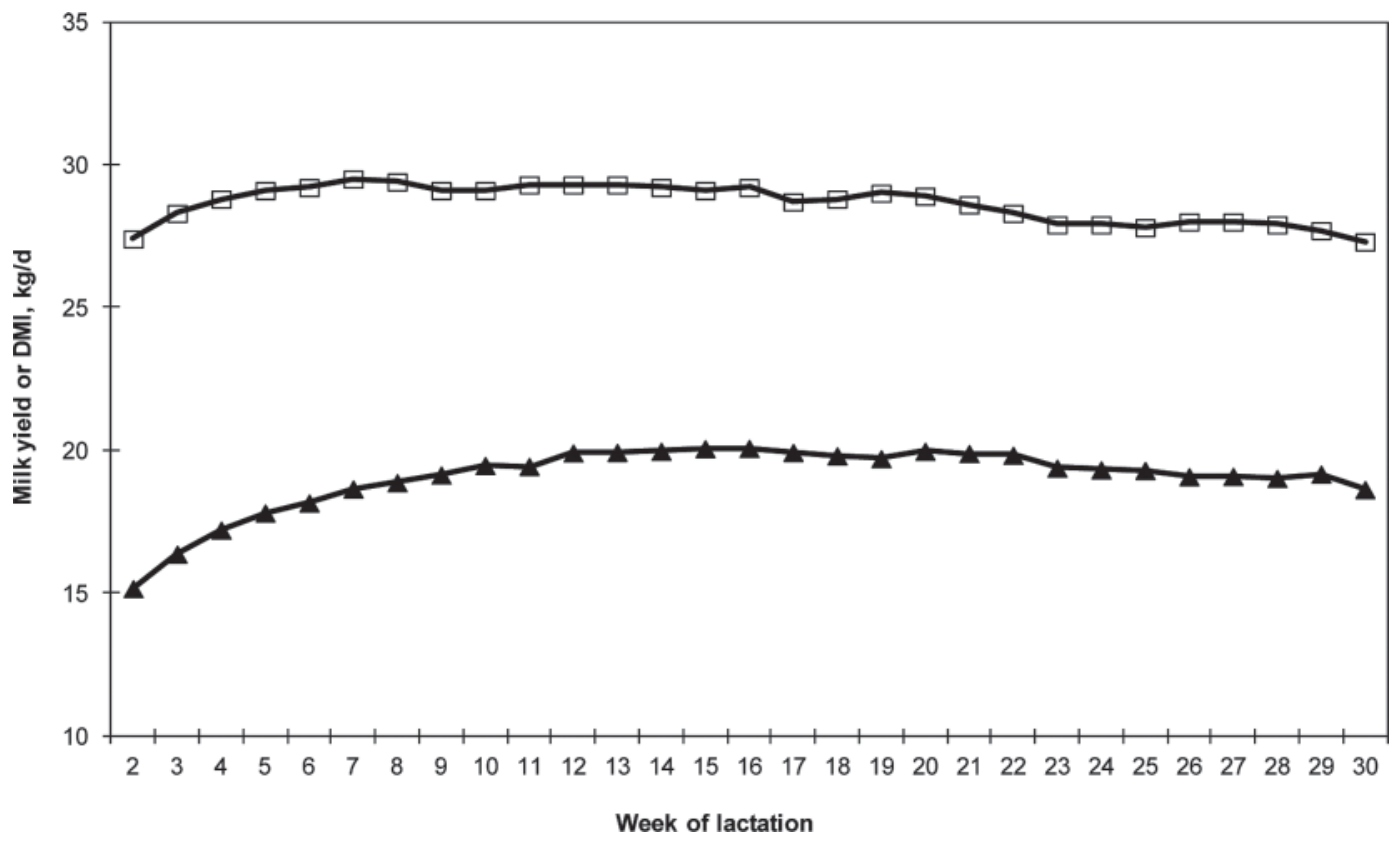

Figure 1. Daily average ECM yield $(\square)$ and DMI $(\boldsymbol{\Delta})$ by week of lactation of primiparous Nordic Red dairy cows on the MTT multiple ovulation embryo transfer (MOET) herd (MTT Agrifood Research Finland, Jokioinen) from 2006 to 2009 (n = 145 cows). 


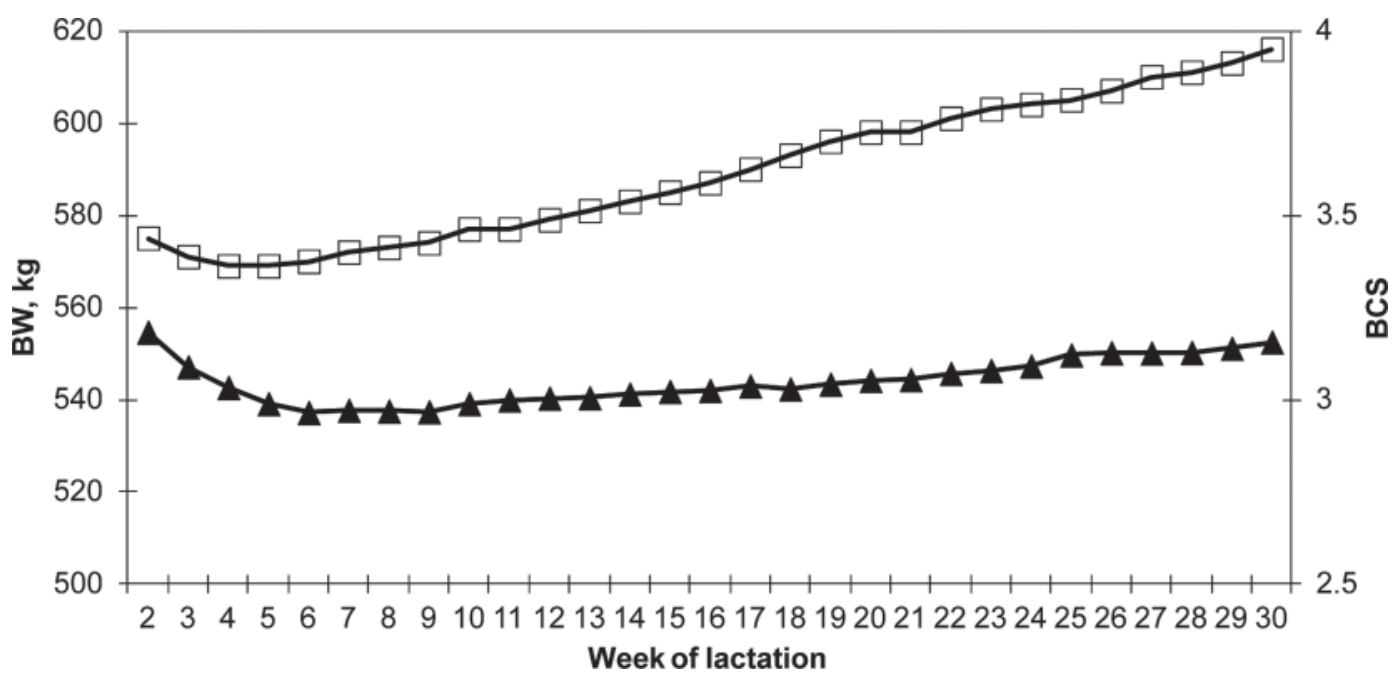

Figure 2. Mean BW $(\square)$ and BCS $(\boldsymbol{\Lambda})$ by week of lactation of primiparous Nordic Red dairy cows on the MTT multiple ovulation embryo transfer (MOET) herd (MTT Agrifood Research Finland, Jokioinen) from 2006 to 2009 (n = 145 cows).

was also significant for each measure. The proportion of total variance due to animals $\left(\mathrm{C}^{2}\right)$ was 0.35 for $\mathrm{REI}_{1}, 0.30$ for $\mathrm{REI}_{2}$, and 0.50 for ECE (Table 3). The root of within-cow variance (SE) illustrates how much variation would be expected if all cows had the same production capacity. We also tested the variance estimation with ECM, where most of the variation (0.71) was found between cows, and the within-cow SE was only $2.3 \mathrm{~kg}$ of ECM. The changes in energy efficiency during lactation are shown in Figure 3. The ECE varied considerably, being highest during the first weeks of lactation and decreasing slowly thereafter until wk 10. After that, it stayed constant for the rest of the lactation. Mean REI was lower in the beginning of lactation than in later lactation. Because of the variation in REI during lactation, correlations between REI in different stages of lactation were only moderate for both $\mathrm{REI}_{1}$ and $\mathrm{REI}_{2}$ (Table 4).

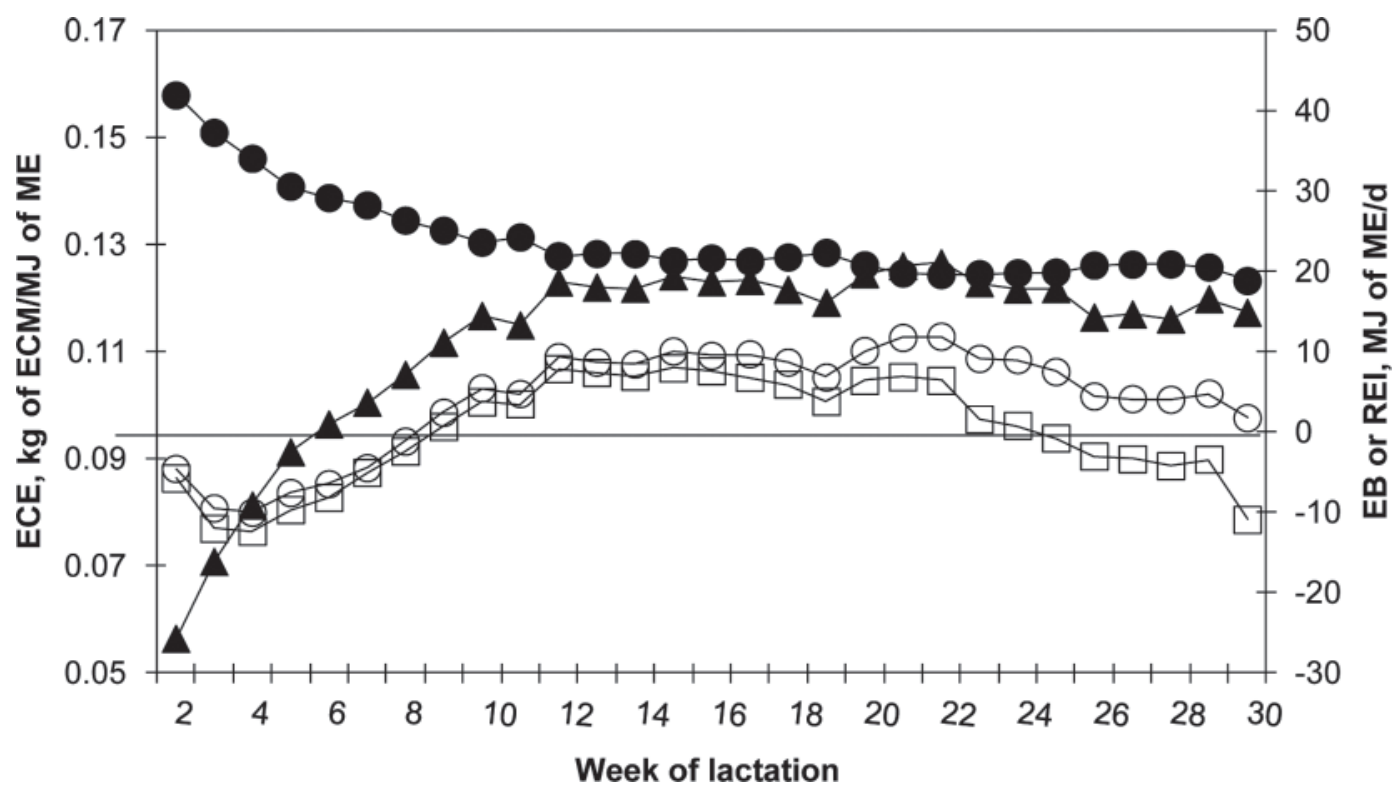

Figure 3. Mean energy conversion efficiency (ECE, $\bullet \mathrm{kg}$ of ECM/MJ of ME), residual energy intake based on official Finnish energy requirements $\left(\mathrm{REI}_{1} ; \mathrm{O}\right)$, residual energy intake based on requirements from current data $\left(\mathrm{REI}_{2}\right.$ : $\left.\square\right)$, and calculated energy balance $(\mathrm{EB}$, $\mathbf{\Delta})$ by week of lactation of primiparous Nordic Red dairy cows on the MTT multiple ovulation embryo transfer (MOET) herd (MTT Agrifood Research Finland, Jokioinen) from 2006 to 2009 ( $\mathrm{n}=145$ cows). 
Table 3. Mean, standard deviation (SD), within-animal standard deviation (SE), and between-animal variance as a proportion of total variance $\left(\mathrm{C}^{2}\right)$ for energy efficiency and energy balance and its indicators during lactation wk 2 to 30

\begin{tabular}{llccc}
\hline Item & Mean & $\mathrm{SD}$ & $\mathrm{SE}$ & $\mathrm{C}^{2}$ \\
\hline $\mathrm{ECM}: \mathrm{ME}, \mathrm{kg} / \mathrm{MJ}$ of ME & 0.133 & 0.020 & 0.014 & 0.50 \\
$\mathrm{REI}_{1}, \mathrm{MJ}$ of ME/d & 3.2 & 23.3 & 18.8 & 0.35 \\
$\mathrm{REI}_{2}, \mathrm{MJ}$ of ME/d & 0.0 & 20.5 & 17.1 & 0.30 \\
Energy balance, MJ of ME /d $_{\text {NEFA, mmol/L }}{ }^{2}$ m & 9.7 & 24.8 & 19.0 & 0.28 \\
Fat:protein ratio & 0.247 & 0.123 & 0.088 & 0.49 \\
\hline
\end{tabular}

${ }^{1}$ Residual energy intake calculated with official Finnish energy requirements (MTT, 2006).

${ }^{2}$ Residual energy intake calculated with energy requirements from current data.

${ }^{3}$ Measured in lactation wk 2, 3, and 5 .

\section{Relationship Between Energy Efficiency and Production, Intake, and Body Traits}

Correlations between energy efficiency, measured as ECE or REI, and milk, intake, body, and EB traits are presented in Table 5. Increased energy efficiency measured as ECE or $\mathrm{REI}_{1}$ was related to increased milk production and decreased feed, and thus energy and protein intake. In contrast, $\mathrm{REI}_{2}$ did not correlate with milk yield but had a positive correlation with DMI, indicating lower intake in more efficient cows. We observed a tendency for higher milk fat content for cows with high feed efficiency. However, no correlation between energy efficiency (ECE, $\mathrm{REI}_{1}$, or $\mathrm{REI}_{2}$ ) and milk protein content was observed.

When ECE was considered as an energy efficiency measurement, an increase in efficiency was associated with BW $(\mathrm{r}=-0.50)$ and BCS loss $(\mathrm{r}=-0.17$; Table $5)$. Because the changes in $\mathrm{BW}$ were accounted for in the calculation of REI, only a low correlation $\left(\mathrm{REI}_{1}\right)$ or no correlation $\left(\mathrm{REI}_{2}\right)$ was observed between REI measures and BW or BCS changes (Table 5).

Calculated EB was highly correlated with ECE ( $\mathrm{r}$ $=-0.96)$ and $\operatorname{REI}_{1}(\mathrm{r}=0.93)$, and a clear positive correlation was found between $\mathrm{EB}$ and $\mathrm{REI}_{2}$ (Table $5)$. This is expected in the case of ECE, because increased use of body energy reserves for milk production increases apparent energy efficiency and decreases the EB. Plasma NEFA concentration and milk fat:protein ratio had a moderate correlation with ECE and $\mathrm{REI}_{1}$, but no correlation between NEFA concentration and $\mathrm{REI}_{2}$ was observed.

\section{Performance of Cows with Different Energy Efficiencies}

Figures 4 and 5 present the energy efficiency, milk yield, energy intake, and daily gain of the cows with high $(\mathbf{H})$ or low $(\mathbf{L})$ energy efficiency defined using either ECE or $\mathrm{REI}_{2}$. Figures $4 \mathrm{~A}$ and $5 \mathrm{~A}$ illustrate the large difference in energy efficiency between $\mathrm{H}$ and $\mathrm{L}$ cows. The cows in the H-ECE group had clearly higher milk yield than the cows in the L-ECE group (average 31.7 vs. $25.3 \mathrm{~kg} / \mathrm{d}$; Figure 4B). This difference in milk yield was not associated with differences in feed intake (Figure $4 \mathrm{C}$ ), but instead milk yield was positively correlated with mobilization of body reserves (Figure 4D). When energetic efficiency was measured by $\mathrm{REI}_{2}$, the higher efficiency was associated with a decrease in DMI (average 16.9 vs. $20.1 \mathrm{~kg}$ of DM/d; Figure 5C), with a small decrease in milk yield at the end of the observation period (Figure 5B). No significant difference was observed in daily gain between H-REI and L-REI cows (Figure 5D).

Table 4. Correlations between cow residual energy intake (REI) averages at different stages of lactation ${ }^{1}$

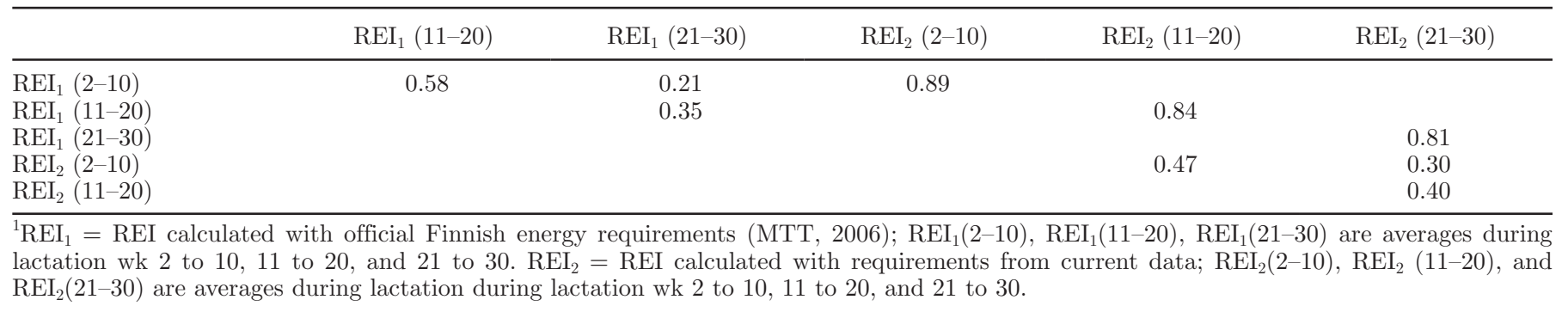


Table 5. Phenotypic correlations between weekly energy efficiency measurements and production, intake, body, and energy balance variables ${ }^{1}$

\begin{tabular}{|c|c|c|c|}
\hline \multirow[b]{2}{*}{ Item } & \multicolumn{3}{|c|}{ Energy efficiency measure $^{2}$} \\
\hline & $\mathrm{ECE}$ & $\mathrm{REI}_{1}$ & $\mathrm{REI}_{2}$ \\
\hline \multicolumn{4}{|l|}{ Yield and composition } \\
\hline ECM, kg/d & 0.58 & -0.41 & 0.00 \\
\hline Milk fat, $\mathrm{kg} / \mathrm{d}$ & 0.64 & -0.48 & -0.09 \\
\hline Milk protein, $\mathrm{kg} / \mathrm{d}$ & 0.42 & -0.26 & 0.10 \\
\hline Milk fat, \% & 0.39 & -0.31 & -0.23 \\
\hline Milk protein, \% & -0.04 & 0.08 & -0.03 \\
\hline \multicolumn{4}{|l|}{ Intake } \\
\hline $\mathrm{DM}, \mathrm{kg} / \mathrm{d}$ & -0.51 & 0.60 & 0.74 \\
\hline $\mathrm{ME}, \mathrm{MJ} / \mathrm{d}$ & -0.52 & 0.61 & 0.75 \\
\hline $\mathrm{CP}, \mathrm{kg} / \mathrm{d}$ & -0.39 & 0.46 & 0.62 \\
\hline \multicolumn{4}{|l|}{ Body traits } \\
\hline $\mathrm{BW}, \mathrm{kg}$ & -0.18 & 0.08 & 0.00 \\
\hline BW change, $\mathrm{kg} / \mathrm{d}$ & -0.50 & 0.13 & 0.00 \\
\hline $\mathrm{BCS}$ & -0.12 & 0.05 & -0.09 \\
\hline BCS change & -0.17 & 0.08 & 0.05 \\
\hline \multicolumn{4}{|l|}{ Energy status } \\
\hline Energy balance, ME MJ/d & -0.96 & 0.93 & 0.78 \\
\hline NEFA, $\mathrm{mmol} / \mathrm{L}$ & 0.59 & -0.32 & -0.06 \\
\hline Milk fat:protein & 0.43 & -0.38 & -0.22 \\
\hline
\end{tabular}

${ }^{1}$ Values in bold differ significantly $(P<0.05)$ from zero (the largest $95 \%$ CI $\mathrm{r} \pm 0.038$ was for the correlation of $\mathrm{REI}_{2}$ and $\mathrm{BW}$ ).

${ }^{2}$ Energy conversion efficiency: ECM $(\mathrm{kg}) / \mathrm{ME}$ intake $(\mathrm{MJ}) ; \mathrm{REI}_{1}$ = residual energy intake calculated with official Finnish energy requirements (MTT, 2006); $\mathrm{REI}_{2}=$ residual energy intake calculated with requirements from current data.
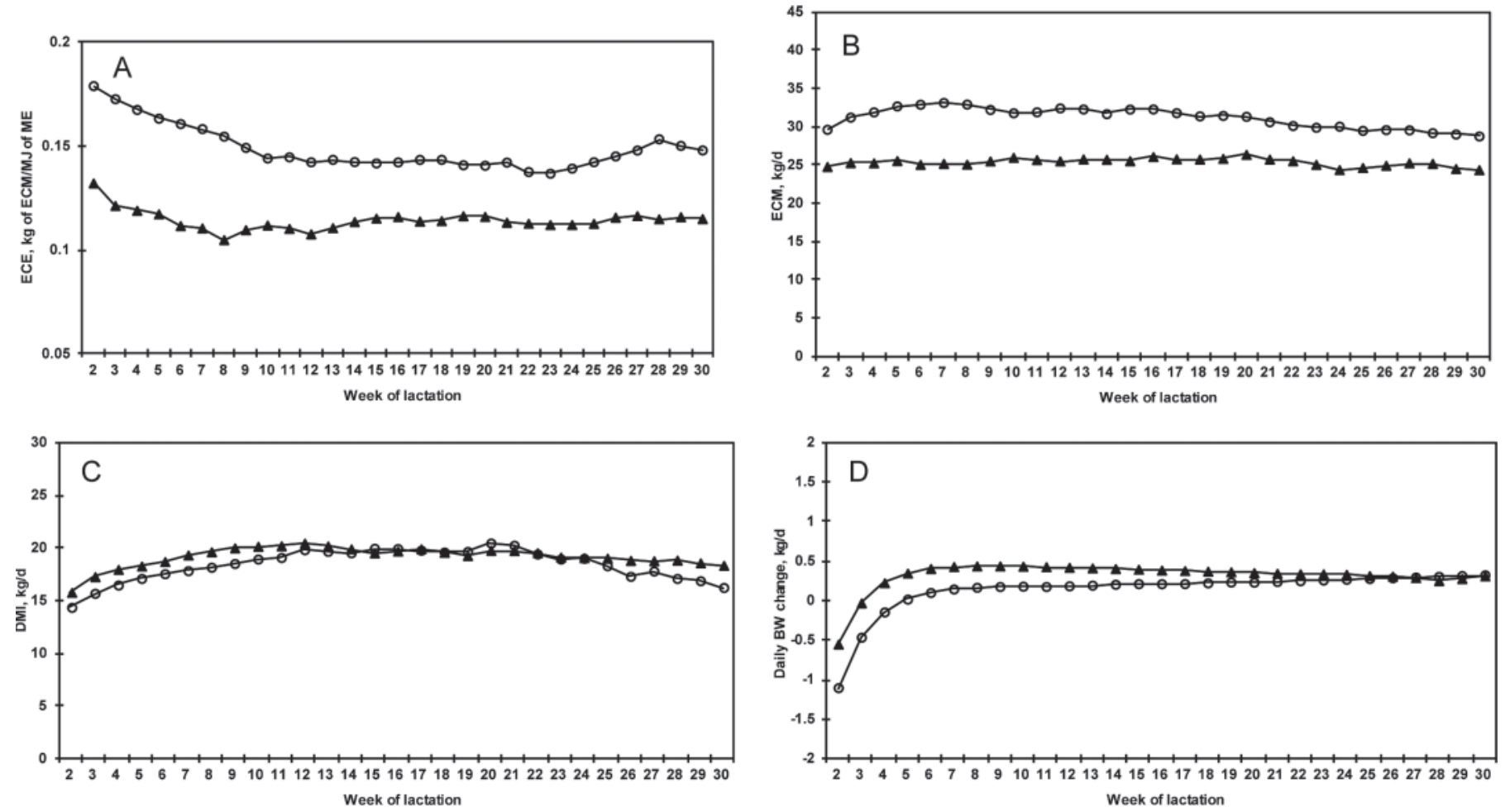

Figure 4. Energy conversion efficiency (ECE; A), ECM yield (B), DMI (C), and daily BW change (D) of primiparous Nordic Red dairy cows with high $(\mathrm{H}-\mathrm{ECE} ; \mathrm{O})$ or low (L-ECE; $\boldsymbol{\Delta}$ ) energy efficiency based on energy conversion efficiency. 

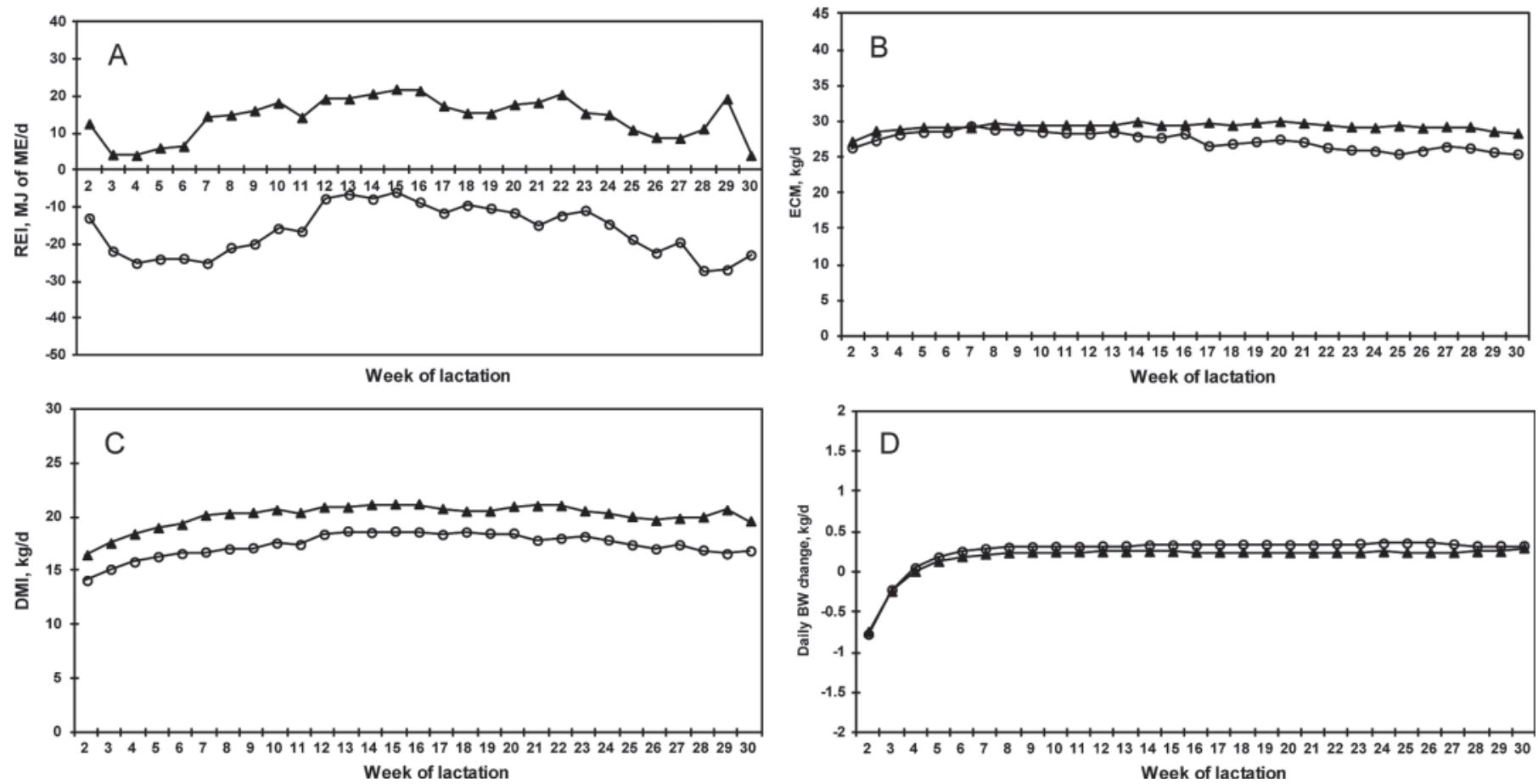

Figure 5. Residual energy intake (REI; A), ECM yield (B), DMI (C), and daily BW change (D) of primiparous Nordic Red dairy cows with high (H-REI; O) or low (L-REI; $\mathbf{\Delta})$ energy efficiency based on residual energy intake $\left(\mathrm{REI}_{2}\right)$.

\section{DISCUSSION}

All animals in the data were high-genetic-merit primiparous cows. They were fed the same diet ad libitum, so the observed differences in performance were due to animal variation and not to diet. Because all cows were in their first lactation, the milk and DMI curves were flat, as is typical with primiparous cows (Coffey et al., 2004; Mäntysaari and Mäntysaari, 2010). For the same reason, BW loss in the beginning of lactation was modest. During the data collection period, cows increased their BW by $47 \mathrm{~kg}$ on average. Because no large changes in BCS occurred, we can assume that the growth was largely gain in lipid-free tissue and, to a lesser extent, regain of fat reserves.

In accordance with the changes in BW and BCS, the calculated EB was only mildly negative during the first weeks of lactation. This agrees well with studies with first-parity cows (Coffey et al., 2004; Mäntysaari and Mäntysaari, 2010), in which the magnitude and duration of energy deficiency was also moderate. Plasma NEFA concentration and milk fat:protein ratio were used as EB indicators, because they have been shown to reflect the energy status, especially in early lactation (Dunshea et al., 1989; Heuer et al., 2000). In the study of Mäntysaari and Mäntysaari (2010), the milk fat:protein ratio had a significant correlation with calculated EB in the beginning of lactation but not in later lactation. In the current data, the average correlation between EB and milk fat:protein ratio during lactation wk 2 to 8 and wk 9 to 18 was -0.51 and -0.22 , respectively. Although the plasma NEFA concentrations were not high in our study, we observed a significant correlation between NEFA concentration and calculated EB $(\mathrm{r}=-0.52)$. The relationship between EB and NEFA concentration is illustrated in Figure 6, where the cows were divided into groups according to the EB. The plasma NEFA concentration of cows with positive or only slightly negative EB (= average over wk 2 to 5 of lactation) was low, and no change in concentration at the beginning of lactation was observed.

\section{Energy Efficiency and Its Phenotypic Variation}

Energy efficiency in the present study was described either by ECE or by $\mathrm{REI}_{1}$ calculated with partial efficiencies for milk, maintenance, and growth estimated on a population level, or by $\mathrm{REI}_{2}$ calculated using the requirements derived from the current data. Thus, the 2 REI values denote the difference in the utilization of energy by the cows in the data relative to the population or current group mean. If the studied group of cows represents the population well, both the REI values should be equal. The average of $\mathrm{REI}_{2}$ was, as 


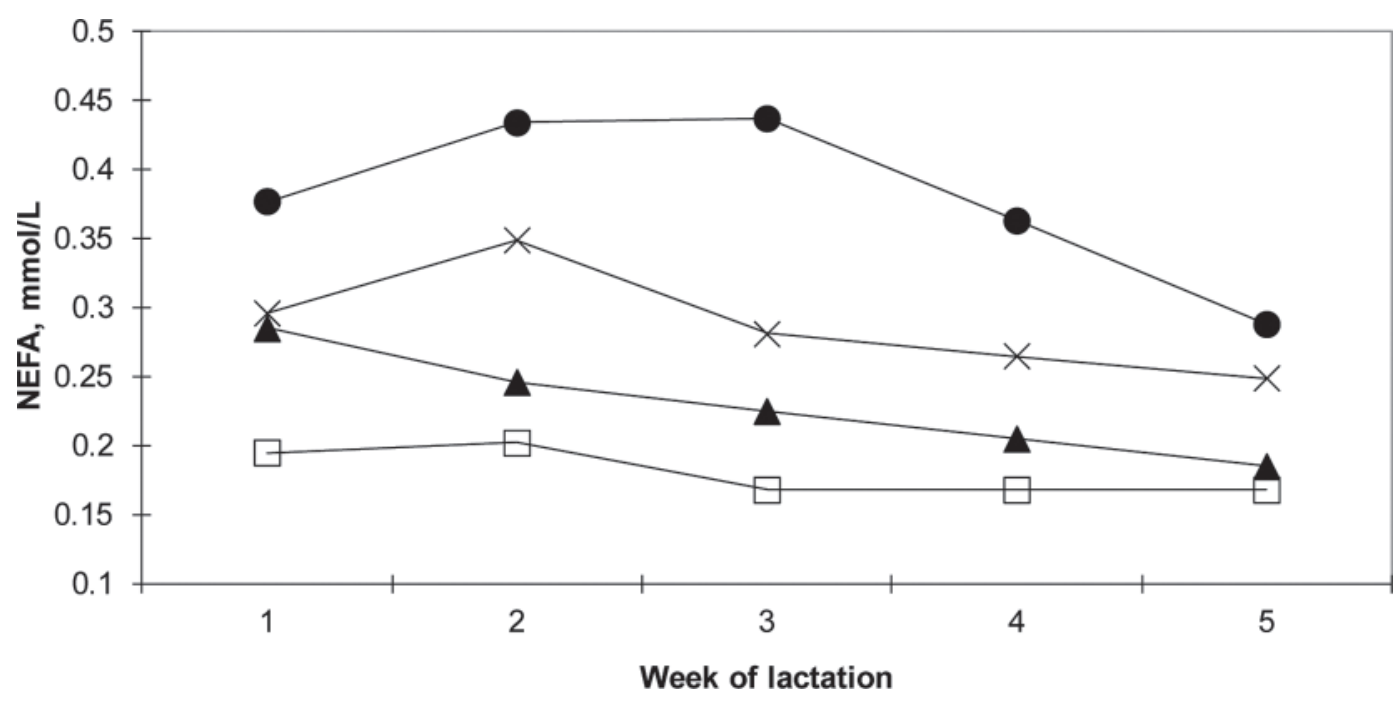

Figure 6. Plasma NEFA concentration during lactation wk 1 to 5 of the primiparous Nordic Red dairy cows with calculated (mean over wk $1-5$ of lactation) energy balance under $-40 \mathrm{MJ}$ of $\mathrm{ME} / \mathrm{d}(\bullet)$, from -40 to $-20 \mathrm{MJ}$ of $\mathrm{ME} / \mathrm{d}(\times)$, from -20 to $0 \mathrm{MJ}$ of $\mathrm{ME} / \mathrm{d}(\mathbf{\Lambda})$, or $>0 \mathrm{MJ}$ of $\mathrm{ME} / \mathrm{d}(\square)$.

expected, $0 \mathrm{MJ}$ of $\mathrm{ME} / \mathrm{d}$, but the average value of $\mathrm{REI}_{1}$ was also close to zero (3.2 MJ of ME/d), which indicates that, on average, energy was used with expected efficiencies. A slightly higher ME intake than predicted by official requirements could be a result of some unavoidable wastage of feed, as speculated by Veerkamp et al. (1995). In their study, the cows' intake of ME was $8 \mathrm{MJ} / \mathrm{d}$ more than what was predicted based on population data.

Although the average efficiency measurements were very close to what was expected, we observed notable variation between cows, as shown in Figures $4 \mathrm{~A}$ and $5 \mathrm{~A}$. In the case of ECE, the variation arose partly from the inability of ECE to distinguish between energy used for maintenance, milk, and BW loss or gain. The energy needed for maintenance is related to BW, which varied significantly in our data. In addition, the partitioning of energy for milk and body tissue varies between cows. The effect of genetic potential of the cow on partitioning of energy is shown by Veerkamp and Emmans (1995) and Yan et al. (2006). In the present data, no large differences were expected in the genetic potential of the cows, but nonetheless, we observed differences among cows in the mobilization of body energy reserves. Thus, genetic selection based on ECE could lead to favoring of cows with long and deep energy deficiency in the beginning of lactation, as seen in Figure $4 \mathrm{D}$. It is also known that dietary factors can affect energy partitioning (Oldham, 1984; Huhtanen, 1998; van Knegsel et al., 2007) and thereafter ECE. In our data, all cows were fed the same diet, which met their nutrient requirements, so the effect of diet on energy partitioning should have been minimal.
With REI, the use of energy for different functions is considered and the use of body reserves is taken into account. Nonetheless, large variation in REI was observed among the cows. In part, the variation in REI reflects the true differences in the energetic efficiency between cows, but it can also be associated with errors in the measures of production, intake, or BW, even if the current data were collected accurately under experimental conditions. Milk yield was recorded only twice a week, which may increase variation. Dry matter intake was recorded daily; however, the wastage of feed cannot be overruled. All cows were fed the same diet ad libitum, and therefore it can be assumed that the influence of negative associative effects (Huhtanen, 1998; Doyle et al., 2005) on the calculated ME intake should be the same for all cows and thus have no influence on the variation among cows. Because of changes in gut fill, the BW of a cow can vary between consecutive measurements, leading to inadequate estimates for BW and BW changes. In the current data, however, the problem was avoided by using predicted BW based on an animal-wise function on time. In the REI models, separate regression coefficients for BW gain and loss were used. On the other hand, no effect of the composition of BW loss or gain was taken into account. The energy content of body mobilization or gain depends on the relative share of fat and protein in BW change. In the beginning of lactation, a unit of BW loss consists of more fat in relation to the protein and water, which leads to a higher energy content of the BW change (Tamminga et al., 1997). In their study, an average $64 \%$ from BW change during the first $8 \mathrm{wk}$ of lactation was from fat and $5 \%$ from protein. However, large differences were 
found between individual cows regarding the amount and composition of mobilization. In our study, all cows were primiparous, which may have affected the composition of the BW change in the beginning as well as in the later lactation. The older and more mature cows were closer to their adult size and probably had more fat relative to protein to be mobilized in the beginning of the lactation and less need for protein gain later in lactation compared with less mature cows. Thus, the degree and composition of BW loss in the beginning of the lactation and gain in later lactation may differ between these cows. On average, the fat content of BW loss in weekly measurements of individual cows during wk 2 to 6 of lactation was $53 \%$, varying from 21 to $99 \%$ in our data when calculated from the change in empty BW fat. The empty BW fat was estimated according to Waltner et al. (1994) using an equation based on BW and BCS. Some variation in REI can arise from the differences in the energy required for activity of the cows. In the present study, however, the differences between cows in activity were minimal because all cows were housed in a tie-stall barn.

The variation in energetic efficiency between cows can arise from differences in digestion and utilization of ME for separate functions. Studies have indicated some differences among cows in their ability to digest a given diet (Trigg and Parr, 1981; Berry et al., 2007), whereas in the studies of Grieve et al. (1976) and Kennedy et al. (2003), no difference in the digestibility of diet between genetically high- and low-merit cows was found. On the other hand, in the study of Richardson and Herd (2004), lower REI (higher efficiency) values were associated with a greater digestibility. According to the study of Yan et al. (2006) and the reviews of Veerkamp and Emmans (1995) and Agnew and Yan (2000), it is unlikely that a large difference exists between cows in the efficiency of use of ME for production. However, some differences may occur because of differences in milk composition (Chwalibog, 1991). The production capacity of the cows can affect energy requirements for maintenance; the high-producing cows had a larger mass of active organs (liver, heart), which increases the maintenance requirements (DiCostanzo et al., 1990). Differences between cows in composition of BW gain can influence the utilization of ME for gain and thus increase the variation in energetic efficiency.

The results of the current study indicated a trend for better energy efficiency in the beginning of the lactation. In the case of ECE, this is easily explained by the increased use of body reserves during the first weeks of lactation. For $\mathrm{REI}_{1}$ and $\mathrm{REI}_{2}$, the effect of stage of lactation was very similar, with a better efficiency compared with population or group mean seen dur- ing the wk 2 to 8 . A corresponding effect of the stage of lactation was reported by Veerkamp and Emmans (1995). The differences in REI during lactation may be related to the difficulties in estimating BW change and its composition during the first weeks after calving (Tamminga et al., 1997). We could speculate that differences exist in ME utilization for separate functions during lactation. The milk fat content is higher during the first weeks of lactation, which may influence the utilization of ME for the production (Chwalibog, 1991). Contrary to that, Yan et al. (2006) found no significant effects of stage of lactation on the efficiency of ME use for production. However, our findings indicate that when comparing REI values of different cows, either the values should be based on the same period of lactation or a reliable estimation for the effect of stage of lactation must be modeled.

\section{Relation of Energy Efficiency with Production, Intake, and Body Traits}

When energy efficiency is based on ECE or $\mathrm{REI}_{1}$, the better efficiency is associated with increased milk, milk fat and milk protein yields and lower feed intake. The correlation between $\mathrm{REI}_{1}$ and production indicates that the energy requirements based on population mean do not fully agree with the requirements of the current cows. Using $\mathrm{REI}_{2}$ as an efficiency estimate, no correlation with milk production was found, as expected. Instead, the increase in efficiency $\left(\mathrm{REI}_{2}\right)$ was mostly associated with lower feed intake. This meant on average $2.7 \mathrm{~kg}$ lower daily DMI for H-REI cows than for L-REI cows. The correlation between $\mathrm{REI}_{2}$ and DMI was 0.74 . In agreement with our results, Veerkamp et al. (1995) and Prendiville et al. (2009) reported the corresponding correlations to be 0.73 and 0.30 , respectively. In the study of Meyer et al. (2008), the low REI beef cows had $21 \%$ lower DMI than high REI cows $(P=0.23)$.

Energy efficiency was not related to milk protein content but higher fat content was associated with better efficiency. This indicates that producing the same ECM with milk high in fat is more energy efficient. In case of ECE, this finding may be related to the fact that increased mobilization of body fat reserves increases both ECE and milk fat content. With $\mathrm{REI}_{2}$, no correlation between BW change and efficiency remained. Thus, BW change cannot be the explanation for the higher milk fat content of the cows with lower $\mathrm{REI}_{2}$. This finding might be associated with the differences in efficiency of ME use for different milk components. Chwalibog (1991) proposed partial efficiency of ME utilization for milk protein and lactose energy deposition to be 0.54 and for fat energy deposition 0.82 . In the 
future use of $\mathrm{REI}_{2}$, it is advisable to divide the average milk energy content (ECM) to energy in fat and energy in other components.

The plasma NEFA concentration increased with increased mobilization of body fat reserves (Dunshea et al., 1989). Thus, the relationship of ECE to BW loss, plasma NEFA concentration, and milk fat:protein ratio, which reflects the energy balance of the cow, are all in line. Moreover, the independence of $\mathrm{REI}_{2}$ and BW change is confirmed by the fact that no correlation between plasma NEFA concentration and $\mathrm{REI}_{2}$ value was found.

Recently, great attention has been given to methane emissions from ruminants. In our study, the comparison of groups with differing energy efficiencies suggests that selection on $\mathrm{REI}_{2}$ would lead to decreased intake without affecting production and BW changes. Because methane production is strongly related to DMI, the decreased DMI of low REI cows should lead to decreased methane production. However, in existing studies, the relationship between REI and methane production has been contradictory. Hegarty et al. (2007) measured reduced daily methane production of steers expressing lower REI, whereas Münger and Kreuzer (2008) reported only a weak relationship between REI and absolute (g/d) or relative ( $\mathrm{g} / \mathrm{kg}$ of DMI) methane emission.

\section{CONCLUSIONS}

The findings indicate that true phenotypic betweenanimal variation exists in energy efficiency among Nordic Red cows. Thus, a phenotypic basis for selection on energetic efficiency exists. If selection were based on ECE, it would lead to increased mobilization of body reserves. On the other hand, selection on REI would lead to a decrease in feed intake without affecting production or BW change. In our data, we found a clear effect of stage of lactation on REI, which could be caused by true differences in utilization of ME during lactation, but could also be related to the lack of knowledge on BW change composition in the beginning of lactation.

\section{ACKNOWLEDGMENTS}

The present work is a substudy of larger projects "Energy balance and feed efficiency in dairy cattle" and "Genetic and nutritional tools to mitigate the environmental impact of milk production." The former project was financed by the Finnish Dairies Association (Helsinki, Finland), Valio Ltd. (Helsinki, Finland), Faba (Vantaa, Finland), and both projects were financed by the Finnish Ministry of Agriculture and Forestry (Helsinki, Finland).

\section{REFERENCES}

Agnew, R. E., and T. Yan. 2000. Impact of recent research on energy feeding systems for dairy cattle. Livest. Prod. Sci. 66:197-215.

Berry, D. P., B. Horan, M. O'Donovan, F. Buckley, E. Kennedy, M. McEvoy, and P. Dillon. 2007. Genetics of grass dry matter intake, energy balance, and digestibility in grazing Irish dairy cows. J. Dairy Sci. 90:4835-4845.

Chwalibog, A. 1991. Energetic efficiency of milk production in Jersey cows. J. Anim. Physiol. Anim. Nutr. (Berl.) 65:206-218.

Coffey, M. P., G. Simm, J. D. Oldham, W. G. Hill, and S. Brotherstone. 2004. Genotype and diet effects on energy balance in the first three lactations of dairy cows. J. Dairy Sci. 87:4318-4326.

Coleman, J., D. P. Berry, K. M. Pierce, A. Brennan, and B. Horan. 2010. Dry matter intake and feed efficiency profiles of 3 genotypes of Holstein-Friesian within pasture-based systems of milk production. J. Dairy Sci. 93:4318-4331.

Collard, B. L., P. J. Boettcher, J. C. M. Dekkers, D. Petitclerc, and L. R. Schaeffer. 2000. Relationships between energy balance and health traits of dairy cattle in early lactation. J. Dairy Sci. 83:2683-2690.

de Vries, M. J., S. van der Beek, L. M. T. E. Kaal-Lansbergen, W. Ouweltjes, and J. B. M. Wilmink. 1999. Modeling of energy balance in early lactation and the effect of energy deficits in early lactation on first detected estrus postpartum in dairy cows. J. Dairy Sci. 82:1927-1934.

DiCostanzo, A., J. C. Meiske, S. D. Plegge, T. M. Peters, and R. D. Goodrich. 1990. Within-herd variation in energy utilization for maintenance and gain in beef cows. J. Anim. Sci. 68:2156-2165.

Doyle, P. T., S. A. Francis, and C. R. Stockdale. 2005. Associative effects between feeds when concentrate supplements are fed to grazing dairy cows: A review of likely impacts on metabolisable energy supply. Aust. J. Agric. Res. 56:1315-1329.

Dunshea, F. R., A. W. Bell, and T. E. Trigg. 1989. Relations between plasma non-esterified fatty acid metabolism and body fat mobilization in primiparous lactating goats. Br. J. Nutr. 62:51-61.

Edmonson, A. J., I. J. Lean, L. D. Weaver, T. Farver, and G. Webster. 1989. A body condition scoring chart for Holstein dairy cows. J. Dairy Sci. 72:68-78.

Grieve, D. G., G. K. Macleod, T. R. Batra, E. D. Burnside, and J. B. Stone. 1976. Relationship of food intake and ration digestibility to estimate transmitting ability, body weight, and efficiency in first lactation. J. Dairy Sci. 59:1312-1318.

Hegarty, R. S., J. P. Goopy, R. M. Herd, and B. McCorkell. 2007. Cattle selected for lower residual feed intake have reduced daily methane production. J. Anim. Sci. 85:1479-1486.

Heuer, C., W. M. Van Straalen, Y. H. Schukken, A. Dirkzwager, and J. P. T. M. Noordhuizen. 2000. Prediction of energy balance in a high yielding dairy herd in early lactation: Model development and precision. Livest. Prod. Sci. 65:91-105.

Huhtanen, P. 1998. Supply of nutrients and productive responses in dairy cows given diets based restrictively fermented silage. Agric. Food Sci. Finl. 7:219-250.

Kennedy, J., P. Dillon, L. Delaby, P. Faverdin, G. Stakelum, and M. Rath. 2003. Effect of genetic merit and concentrate supplementation on grass intake and milk production with Holstein Friesian dairy cows. J. Dairy Sci. 86:610-621.

Korver, S. 1988. Genetic Aspects of feed intake and feed efficiency in dairy cattle: A review. Livest. Prod. Sci. 20:1-13.

Legates, J. E. 1990. Efficiency of feed utilization in Holsteins selected for yield. J. Dairy Sci. 73:1533-1536.

MAFF. 1975. Energy allowances and feeding systems for ruminants. In: Ministry of Agriculture, Fisheries and Food Technical Bulletin, No. 33. Ministry of Agriculture, Fisheries and Food, London, UK. 
MAFF. 1984. Energy allowances and feeding systems for ruminants. In: ADAS Reference Book, No. 433. Ministry of Agriculture, Fisheries and Food, London, UK.

Mäntysaari, P., H. Khalili, J. Sariola, and A. Rantanen. 2007. Use of barley fibre and wet distillers' solubles as feedstuffs for Ayrshire dairy cows. Anim. Feed Sci. Technol. 135:52-65.

Mäntysaari, P., and E. A. Mäntysaari. 2010. Predicting early lactation energy balance in primiparous Red Dairy Cattle using milk and body traits. Acta Agric. Scand. A 60:79-87.

Meyer, A. M., M. S. Kerley, and R. L. Kallenbach. 2008. The effect of residual feed intake classification on forage intake by grazing beef cows. J. Anim. Sci. 86:2670-2679.

Miglior, F., B. L. Muir, and B. J. Van Doormaal. 2005. Selection indices in Holstein cattle of various countries. J. Dairy Sci. 88:12551263.

MTT. 2006. Rehutaulukot ja ruokintasuositukset (Feed tables and feeding recommendations) [online]. MTT Agrifood Research Finland, Jokioinen. Accessed Dec. 10, 2008. http://www.mtt.fi/rehutaulukot/.

Münger, A., and M. Kreuzer. 2008. Absence of persistent methane emission differences in three breeds of dairy cows. Aust. J. Exp. Agric. 48:77-82.

Nousiainen, J., M. Rinne, M. Hellämäki, and P. Huhtanen. 2003. Predicting of the digestibility of the primary growth of grass silages harvested at different stage of maturity from chemical composition and pepsin-cellulase solubility. Anim. Feed Sci. Technol. 103:97111.

Oldham, J. D. 1984. Protein-energy interrelationships in dairy cows. J. Dairy Sci. 67:1090-1114.

Prendiville, R., K. M. Pierce, and F. Buckley. 2009. An evaluation of production efficiencies among lactating Holstein-Friesian, Jersey, and Jersey $\times$ Holstein-Friesian cows at pasture. J. Dairy Sci. 92:6176-6185.

Richardson, E. C., and R. M. Herd. 2004. Biological basis for variation in residual feed intake in beef cattle. 2. Synthesis of results following divergent selection. Aust. J. Exp. Agric. 44:431-440.

Roche, J. R., K. A. Macdonald, G. R. Burke, J. M. Lee, and D. P. Berry. 2007. Associations among body condition score, body weight, and reproductive performance in seasonal-calving dairy cattle. J. Dairy Sci. 90:376-391.

Sjaunja, L. O., L. Baevre, L. Junkkarinen, J. Pedersen, and J. Setälä. 1990. A Nordic proposal for an energy corrected milk (ECM) formula. Pages 156-157 in Proc. 27th Session of International Committee of Recording and Productivity of Milk Animal, Paris, France.

Smothers, C. D., B. R. Bell, D. O. Richardson, B. F. Hollon, E. D. Moore, and J. R. Owen. 1986. Correlated response in feed efficiency accompanying selection for milk yield in Jerseys. J. Dairy Sci. 69:2370-2378

Tamminga, S., P. A. Luteijn, and R. G. M. Meijer. 1997. Changes in composition and energy content of liveweight loss in dairy cows with time after parturition. Livest. Prod. Sci. 52:31-38.

Trigg, T. E., and C. W. Parr. 1981. Aspects of energy metabolism of Jersey cows differing in breeding index. Proc. N.Z. Soc. Anim. Prod. 41:44-47.

van Knegsel, A. T. M., H. van den Brand, J. Dijkstra, W. M. van Straalen, M. J. W. Heetkamp, S. Tamminga, and B. Kemp. 2007. Dietary energy source in dairy cows in early lactation: Energy partitioning and milk composition. J. Dairy Sci. 90:1467-1476.

Veerkamp, R. F., and G. C. Emmans. 1995. Sources of genetic variation in energetic efficiency of dairy cows. Livest. Prod. Sci. 44:87-97.

Veerkamp, R. F., G. C. Emmans, A. R. Cromie, and G. Simm. 1995. Variance components for residual feed intake in dairy cows. Livest. Prod. Sci. 41:111-120.

Waltner, S. S., J. P. McNamara, J. K. Hillers, and D. L. Brown. 1994 Validation of indirect measures of body fat in lactating cows. J. Dairy Sci. 77:2570-2579.

Wilmink, J. B. M. 1987. Adjustment of test-day milk, fat and protein yield for age, season and stage of lactation. Livest. Prod. Sci. $16: 335-348$

Yan, T., C. S. Mayne, T. W. J. Keady, and R. E. Agnew. 2006. Effects of dairy cow genotype with two planes of nutrition on energy partitioning between milk and body tissue. J. Dairy Sci. 89:1031-1042. 